\section{On the relationship between critical thinking and indirect request strategy use of EFL learners}

Rahimi, Masoud

Bu-Ali Sina University, Hamedan, Iran (

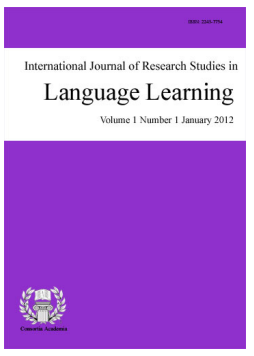

ISSN: $2243-7754$

Received: 2 September 2015

Revised: 9 October 2015

DOI: $10.5861 / \mathrm{ijrs} 11.2015 .1325$
Accepted: 2 November 2015

\title{
Abstract
}

The present study aimed at investigating the relationship between EFL learners' critical thinking and their indirect request strategy use. To this end, one hundred learners learning English as a foreign language at private language institutes in Sanandaj, Iran, were selected as the participants of the study. The participants took the California Critical Thinking Skills Test (CCTST) form B developed by Facione and Facione (1993) and the English Discourse Completion Test (EDCT) adopted from Rose (1994). Pearson product-moment correlation and linear regression analyses were carried out to analyse the data. The results of the Pearson product-moment correlation analysis indicated that critical thinking significantly correlated with the indirect request strategy use of EFL learners. The results of linear regression analysis revealed that critical thinking was a strong predictor of the indirect request strategy use of EFL learners. The findings imply that EFL learners who are competent in critical thinking would frequently use indirect request strategies.

Keywords: critical thinking; indirect request strategy use; EFL learners 


\section{On the relationship between critical thinking and indirect request strategy use of EFL learners}

\section{Introduction}

\subsection{Request Strategies}

In order to communicate effectively, EFL/ ESL learners should promote their knowledge of grammar, text organization, and pragmatic competence of the language. Pragmatic competence could be regarded as the speaker's knowledge of using the target language appropriately and politely. This competence is further related to the speaker's understanding and proper application of speech acts (Koike, 1989). Austin (1962) considered speech acts as acts which could be performed by utterances such as giving orders, making promises, complaining and requesting. As requesting occurs in a situation of inequality the speaker should always regard the principles of politeness no matter what the object of his/her request is (Erving, 1967). Request is defined as "an act of asking politely or formally for something" (Balci, 2009, p. 16). Blum-Kulka (1987) claims that politeness is defined as the interactional balance achieved between two needs: The need for pragmatic clarity and the need to avoid coerciveness (p. 131). Blum-Kulka (1987) suggests that conventional indirectness which contains pragmatic clarity and avoids coercion (i.e. it is face saving) is perceived as a more polite request. Thus, direct request strategies which use coerciveness and non-conventional indirect request strategies which lack pragmatic clarity might be regarded as impolite request strategies (Blum-Kulka, 1987). The framework of the present study is more in line with the conventional indirectness in request strategies.

A number of studies have been conducted to investigate EFL learners' request strategies. Tajeddin and Tayebipour (2012), for instance, investigated the effect of dynamic assessment (DA) on 49 university EFL students' acquisition of request and apology strategies. They randomly assigned the subjects to 1 of 4 groups consisting of two DA and two non-dynamic assessment (NDA) groups. Both DA and NDA groups were taught how to use appropriate request and apology strategies. DA groups were taught based on DA procedures and NDA groups did not receive any treatment on DA procedures. All participants completed a pre-test, a post-test a delayed post-test of request and apology speech acts. The findings indicated that DA groups outperformed NDA groups. It was also revealed that DA groups of both high and low proficiency levels differed significantly from pre-test to post-test to delayed post-test. However, NDA group did not show such a difference. The results also showed no interaction between proficiency and instruction and they suggested that instruction had a significant effect on post-test and delayed post-test performance of the students.

Jalilifar (2009) conducted a study to examine the request strategies used by Iranian EFL learners and Australian native speakers of English. Ninety six BA and MA Persian students and 10 native speakers of English took part in the study. A discourse completion test was used to collect the required data. The results indicated that EFL learners with higher proficiency overused indirect requests whereas the native group was characterised by the more balanced use of this strategy. The results further showed that the lower proficiency learners overused direct strategies.

Rue, Zhang, and Shin (2007) investigated the request strategies of twelve office workers in Korea. The required data was collected through video-taping of three role-play scenarios performed by the participants. The findings revealed that Korean request strategies were chosen primarily according to power status, i.e. the higher the power status of the addressee the more indirect request strategies were used. Furthermore, the findings revealed that Korean speakers appeared to be more indirect to the addressees who were superiors and equal work members than to juniors. The findings also indicated that hints were used extensively but proportional to the level of power ranks, i.e. the lower the power rank of the addressee the less preference for strong hint was 
displayed.

Umar (2004) compared the request strategies used by advanced Arab learners of English and the request strategies used by native speakers of English. Twenty Arab students at four universities and 20 British students at three universities took part in the study. For collecting the required data a discourse completion test was used. The results suggested that the two groups adopted similar strategies when addressing their requests to equals or people in higher positions. In such cases the subjects heavily relied on conventionally indirect strategies. The results also suggested that Arab students showed more direct request strategies than their British counterparts when their requests were addressed to people in lower positions. The results revealed that the native speakers of English used more semantic and syntactic modifiers than their Arab counterparts, and as a result, their requests sounded more polite and tactful. The investigator attributed this to the linguistic superiority of the native speakers.

Memarian (2012) examined Iranian graduate students' use of requestive head act strategies in terms of two factors of degree of familiarity and social power. The study further aimed at determining any signs of pragmatic transfer from the first language to the second language and investigated the pragmatic competence of Iranian graduate students regarding this specific speech act. One hundred university students participated in the study. Discourse completion test was used to collect the required data. The findings indicated possible signs of transfer from the first language to the second language. The results also showed evidence on the development of interlanguage by Iranian graduate students. With regard to the two factors of social power and degree of familiarity, Iranian learners were found to need more education on the choice of strategies used, because they employed strategies similar to the ones used by native speakers of Persian rather than to those used by the British native speakers. With regard to the choice of strategies, preparatory strategy was the strategy most frequently used by Iranian graduate students.

Sofwan and Rusmi (2011) investigated the request strategies used by non-native speakers of English. The purpose was to examine the social variables of power, distance and rank of imposition in choosing the request strategies. Ten male and ten female English teachers of junior high schools took part in the study. Oral discourse completion test was used to collect the data. The results indicated that most of the teachers used conventionally indirect strategies followed by direct strategies and non-conventionally indirect strategies. The results further indicated that the higher the rank of imposition the more indirect request strategies were use. In addition, Blum-Kulka (1987) investigating the Hebrew and English native speakers' perceptions of the indirect and polite requests, found that the indirect and polite requests were perceived as different from each other. Therefore, the speakers' indirect request strategies were not necessarily perceived as polite.

Shahrokhi (2012) conducted a study to investigate how request speech acts were formulated with regard to the face needs of Persian male native speakers. Discourse completion test was used to collect the required speech acts. The results resulted in the categorisation and tabulation of universal and culture-specific request strategies performed by Persian male speakers. The findings further proposed that as far as request speech acts were concerned Persian males' linguistic choice was affected by contextual variables. In addition, Tan and Farashaiya (2012) examined the effect of explicit instruction of formulaic politeness strategies on the use of requests of 50 Malaysian undergraduate students. An open-ended discourse completion test, a listening test and an acceptability test were used to collect the data. The results indicated a positive effect of teaching formulaic politeness strategies on Malaysian undergraduate students' use of requests.

Malaz, Rabiee, and Ketabi (2011) investigated the request strategies used by Persian EFL learners. Moreover, they investigated the effects of pragmatic instruction on the participants' noticing constrained by different types of treatment tasks. Thirty learners were divided into two instructional conditions, i.e. a form-comparison condition and a form-search condition. For collecting the data discourse completion test was used to find the request strategies used by each group in pre-tests and post-tests. The data were examined with regard to the extent to which the learners had noticed the appropriate manner of request realisation in English 
and were further compared with the post-test. The results indicated that during the treatment most of the learners noticed the target request forms in the form-comparison condition in comparison to/with the form-search condition.

Economidou-Kogetsidis (2013) conducted a study to investigate whether the written requests of the discourse completion test are similar to naturally occurring requests in a situation where somebody is talking on the telephone. They investigated the degree of directness, internal modification and request perspective. The findings indicated that there were significant differences between the requests of the discourse completion test and naturally occurring requests. The findings further indicated that these two types of requests followed similar trends in terms of directness and lexical modification. Mohammadi and Tamimi Sa'd (2013) revealed that Iranian EFL learners relied on positive and negative politeness when they use requests. They found that native speakers perceived most of the Iranian EFL learners' requests as partially polite rather than entirely polite or impolite. Moreover, they indicated that some elements that could contribute to the politeness of Iranian EFL learners' requests were level of directness, use of certain semantic formulas, honorifics and in-group markers and lack of pre-requests (p. 37).

Takahashi (1992) indicated that indirect request strategies were transferable for some contexts but not for other contexts. As some factors such as familiarity, gender and social status were tightly controlled, it was revealed that some contextual factors other than the aforementioned variables played a prominent role in the transferability of indirect request strategies. Those contextual factors may include the content of the situations and/or request imposition. Similarly, Anani Sarab and Alikhani (2015) revealed that Iranian EFL learners' awareness and production of request strategies were developed through instruction. Blum-Kulka and Olshtain (1984) maintain that the realisation of speech acts originate from three kinds of variability: the situational variability (i.e. variations across social constraints), the cross-cultural variability (i.e. variations across socially differentiated situations) and the individual variability (e.g. age, sex, level of education).

\subsection{Critical Thinking}

A wide range of definitions have been suggested for critical thinking. In the present study the conception of critical thinking was more in line with the definitions of Wang (2009), Davidson (1998) and Facione (2011). Wang (2009) considers critical thinking as reflective and reasonable thinking. Davidson (1998) claims that critical thinkers interpret, analyse, evaluate and infer whatever they encounter. As Facione (2011) put it,

We understand critical thinking to be purposeful, self-regulatory judgment which results in interpretation, analysis, evaluation, and inference, as well as explanation of the evidential, conceptual, methodological, criteriological, or contextual considerations upon which that judgment is based. CT is essential as a tool of inquiry. As such, CT is a liberating force in education and a powerful resource in one's personal and civic life. While not synonymous with good thinking, CT is a pervasive and self-rectifying human phenomenon. The ideal critical thinker is habitually inquisitive, well-informed, trustful of reason, open-minded, flexible, fair-minded in evaluation, honest in facing personal biases, prudent in making judgments, willing to reconsider, clear about issues, orderly in complex matters, diligent in seeking relevant information, reasonable in the selection of criteria, focused in inquiry, and persistent in seeking results which are as precise as the subject and the circumstances of inquiry permit. Thus, educating strong critical thinkers means working toward this ideal. It combines developing CT skills with nurturing those dispositions which consistently yield useful insights and which are the basis of a rational and democratic society (p. 27).

A number of studies have been conducted to investigate critical thinking in the field of education. Rezaee, Farahian, and Ahmadi (2012) suggested that critical thinking had a significant effect on functioning in education. McBride and Bonnette (1995) claimed that in order to sufficiently structure the learning environment, the 
On the relationship between critical thinking and indirect request strategy use of EFL learners

teachers should apply and foster critical thinking. In a similar vein, Soodmand Afshar, Rahimi, and Rahimi (2014) found a significant correlation between critical thinking and academic achievement of Iranian EFL learners. Additionally, critical thinking strongly predicted academic achievement. They also found a significant correlation between critical thinking and autonomy, but critical thinking did not correlate with instrumental motivation.

Niu, Behar-Horenstein, and Garvan (2013) investigating the effect of instructional interventions on students' critical thinking skills, found that instructional interventions had a significant effect on students' critical thinking skills. They proposed that students' critical thinking was crucial for their higher education. Similarly, Soodmand Afshar and Rahimi (2014) indicated that critical thinking significantly correlated with emotional intelligence and speaking ability of Iranian EFL learners. Furthermore, they indicated that critical thinking strongly predicted speaking ability. The findings imply that EFL learners with a high level of critical thinking are more capable in speaking. Dewey (1933) claimed that critical thinking was quite similar to reflective thinking. He proposed that reflective thinking was a part of critical thinking. He further claimed that reflective thinking was regarded as making judgements about events. As King and Kitchener (1994) pointed out, reflective thinking contains seven developmental stages with reflective judgment in its highest stage. They suggest that people with reflective judgment acknowledge that there is no right answer and they disagree with the best solution of a dilemma. They further propose some adult learners with great wisdom have reflective judgment.

Brabeck (1983) investigated the relationship between critical thinking and adult intellectual development described as reflective judgment. The participants' critical thinking scores were matched on high and low extremes and were compared with their scores on the reflective judgment interview. The findings indicated that students at higher educational levels obtained higher scores on the reflective judgment measure. The findings also revealed that students with higher critical thinking skills outperformed their low critical-thinking counterparts on the reflective judgment interview. In a similar vein, Dwyer, Hogan and Stewart (2015) found that critical thinking disposition had a significant effect on reflective judgement performance. Hence, adult learners' critical thinking and reflective judgment should be highly regarded in adult education.

Soodmand Afshar and Rahimi (2015) investigated the relationship among reflective thinking, emotional intelligence, and speaking ability of 150 EFL university students. They indicated that reflective thinking and emotional intelligence significantly and positively predicted speaking ability. Furthermore, among the components of emotional intelligence, reality testing (i.e. the ability to figure out the relationship between what is emotionally experienced and what objectively exists) significantly predicted speaking ability, and self-actualisation (i.e. the ability to be aware of one's potential capabilities and to do what one can do) significantly predicted reflective thinking. Saadé, Morin, and Thomas (2012) conducted a study to investigate critical thinking in a virtual learning environment. They conducted a web-based course to determine the parts of the course that critical thinking was perceived to occur. They adopted two categories of learning modules for the course, namely resources and interactive components. For collecting the required data the ART scale was used to measure critical thinking subjectively. The findings revealed that the students perceived interactivity to be critical-thinking-oriented.

Liaw (2007) conducted a study to examine the effectiveness of promoting EFL learners' critical thinking skills by a content based approach. Two groups of junior high school students took part in the study. The required data was collected through a critical thinking assessment, class assignments and a teacher-constructed language proficiency test. The findings revealed that critical thinking and content area knowledge simultaneously increased. Ganapathy and Kaur (2014) claimed that higher order thinking skills stimulated the ESL learners' analysis, evaluation and creative thought in and outside the classroom. Furthermore, they indicated that higher order thinking skills could enhance ESL learners' writing ability and interest in ESL writing lessons. Khatib and Shakouri (2012) proposed that critical thinking could be developed through literature reading. They claimed that its cultural load, structural complexity and non-normative use of language as claimed, is exactly what can be employed to enrich language teaching and learning experiences, and enhance critical thinking ( $\mathrm{p}$. 
107).

Nikou, Bonyadi, and Amirikar (2015) using the California critical thinking test (form B), found a positive relationship between critical thinking skills and 140 Iranian EFL learners' writing quality. Fahim and Mirzaii (2013) indicated that writing instruction and dialogic critical thinking (i.e. the engagement of learners in dialogue) positively and significantly influenced Iranian EFL learners' argumentative writing. Nasirahmadi (2014) found a positive and significant correlation between critical thinking and Iranian EFL learners' reading comprehension. Furthermore, he indicated that critical thinking strongly predicted the learners' success or failure in the IELTS academic reading section. Lloyd and Bahr (2010) found that students did not perceive critical thinking in different ways and that this might not limit their achievement as a critical graduate attribute. They suggested that both academics and students substantively perceived similar definitions and understandings of critical thinking.

van Gelder (2001) claimed that in order to improve critical thinking in students, teachers should use educational technologies. He proposed that critical thinking was highly valued but difficult to teach effectively. He introduced the Reason! Able software developed at the University of Melbourne as part of a general method aimed at enhancing critical thinking skills. He claimed that students who used Reason! Able software appeared to make dramatic gains in critical thinking skills. Demirhan, Beşoluk, and Önder (2011) investigated the grades of 60 pre-service science teachers. They used the California critical thinking disposition inventory and concluded that while the pre-service science teachers' critical thinking disposition decreased their cumulative grade point averages increased over the years. Mejia and Molina (2007) assumes that the classroom triggers and promotes critical autonomous thinking in students and this ability might be applied to other contexts.

Myers and Dyer (2006) conducted a study to determine the influence of student learning style on critical thinking. The participants were 135 students studying at the University of Florida. Their results showed that there was no difference between the critical thinking of males and females. They found that students with deeply embedded abstract-sequential learning style preferences had significantly higher critical thinking ability. They further suggested that there was no difference in critical thinking ability of students of other learning styles. In addition, they claimed that if abstract-sequential learners were inherently adept at thinking critically, there would be no need for teachers to focus intently on teaching strategies that addressed this learning style. Additionally, they found that in contrast with abstract-sequential learners, concrete-sequential, abstract-random and concrete-random learners might need additional attention through instructional methods and techniques that could enhance their critical thinking skills.

Lun, Fischer, and Ward (2010) examining the possible differences in critical thinking between Asian and New Zealand European students, found that that New Zealand European students performed better on critical thinking skills than Asian students. They suggested that English proficiency might explain these differences. The findings further revealed that Asian students relied more on dialectical thinking to solve critical thinking problems. Furthermore, they found that culture had an influence on critical thinking skills. Yang (2012) conducted a study to investigate the transfer of critical thinking skills and dispositions from pre-service teacher training to classroom practice and student achievement. The participants of the study were two 7th and two 8th grade classes. These two classes were randomly assigned as experimental and comparison groups. In the experimental group critical thinking skills were integrated into the instruction and in the comparison group the traditional way of instruction was applied. The findings suggested that the teachers successfully developed and fostered the students' critical thinking skills and dispositions in the integrated instruction and further improved the students' achievement.

Birjandi and Alizadeh (2012) investigated critical thinking skills in three English textbooks of Top notch, Interchange, and English files series which were widely taught in different language institutes in Iran. They found that among the critical thinking skills analysis, induction, and evaluation were included weakly and deduction was used moderately. Manalo, Kusumi, Koyasu, Michita, and Tanaka (2013) investigated the effect of some culture-related factors on the critical thinking use of 363 undergraduate university students from Kyoto and 
Okinawa in Japan, and Auckland in New Zealand. They indicated that some culture-related factors such as self-construal (i.e. independence or interdependence), regulatory mode, and self-efficacy had significant effect on the students' critical thinking use. Furthermore, they revealed that there was no difference between the groups on measures of critical thinking use.

Paton (2011) conducted a study to investigate Asian students' critical thinking and English as an academic lingua franca. He undertook some interviews with both postgraduate and undergraduate students in three major universities in China and one in India to find their perceptions of critical thinking and English as an academic lingua franca. He found that there was a significant level of understanding of critical thinking and its relationship to English as an academic lingua franca. He also found that critical thinking was part of the framework of humanity not an attribute related to one's nationality or culture.

\subsection{Purpose of the Study}

As the above literature suggests critical thinking and the use of request strategies seem to be important factors in EFL learning. However, it remains unclear whether critical thinking has a positive, a negative or no relationship with EFL learners' indirect request strategy use. This study set out to investigate the relationship between EFL learners' critical thinking and indirect request strategy use, and also examined the amount of the dependent variable (i.e. indirect request strategy use) that could be accounted for by the independent variable (i.e. critical thinking). Therefore, the following research questions were addressed:

$>\quad$ Is there any significant relationship between EFL learners' critical thinking and their indirect request strategy use?

$>\quad$ Does critical thinking significantly predict EFL learners' indirect request strategy use?

\section{Methodology}

\subsection{Participants}

One hundred EFL learners were selected as the participants of the study. The study was carried out in several private language institutes in Sanandaj, Iran. In order to control the proficiency level of the participants, only advanced EFL learners (as determined by the principles of the institutes) were selected. They were adult EFL learners above 18 .

\subsection{Instruments}

The critical thinking skills test is labelled "The California Critical Thinking Skills Test form B" developed by Facione and Facione (1993). There are 34 multiple choice questions each with one correct answer. The CCTST includes five areas of evaluation, inference, analysis, inductive reasoning and deductive reasoning. Facione, Facione, Blohm, Howard, and Giancarlo (1998) found this test and its subscales enjoyed acceptable reliability of 0.78 (calculated through KR-20). Furthermore, they found that the test measured precisely what it purported to measure (i.e. construct validity).

The English Discourse Completion Test adopted from Rose (1994) was applied to assess the request strategies (i.e. direct and indirect request strategies) of the learners. There are eight situations described in the test. The learners were required to read the description of each situation and write down what they would say in that situation. To ensure the validity of the EDCT, it was pilot tested with 50 EFL learners. Kaiser-Meyer-Olkin (KMO) index was 0.85 which was adequate. Bartlett's Test of Sphericity was also significant which revealed significant correlation among the items of the EDCT. Furthermore, the EDCT was shown to enjoy a reliability index of 0.84 (calculated through Cronbach's Alpha consistency index). 


\subsection{Procedures}

The California Critical Thinking Skills Test (CCTS) form B and the English Discourse Completion Test (EDCT) were given to the participants in two different sessions. The purposes and processes of answering the two tests were explained to the participants. The participants wrote down their names on both instruments. Then for CCTS, they chose the options they thought were the right ones and for EDCT, in each situation they wrote down a sentence in the form of request which they thought was appropriate for the situation.

\subsection{Data analysis}

To find out any possible relationship between critical thinking and EFL learners' indirect request strategy use, a Pearson product-moment correlation analysis was run. A linear regression analysis was further carried out to investigate whether critical thinking had any contribution to and/or it was a significant predictor of EFL learners' indirect request strategy use.

\section{Results}

Having collected the data through the two research instruments, namely the California Critical Thinking Skills Test (CCTST) form B developed by Facione and Facione (1993) and the English Discourse Completion Test (EDCT) adopted from Rose (1994), the researcher analysed the data using a Pearson product-moment correlation analysis and a linear regression analysis. To investigate whether there is any significant relationship between EFL learners' critical thinking and their indirect request strategy use, a Pearson product-moment correlation was run. The results are summarised in Table 1:

\section{Table 1}

Pearson Product-Moment Correlation, Investigating the Relationship between EFL Learners' Critical Thinking and their Indirect Request Strategy Use

\begin{tabular}{llc}
\hline & & Indirect request strategy use \\
\hline \multirow{3}{*}{ Critical thinking } & Pearson correlation & .532 \\
& Sig. (2-tailed) & .000 \\
& $\mathrm{~N}$ & 100 \\
\hline
\end{tabular}

As shown in Table 1, critical thinking significantly correlated with EFL learners' indirect request strategy use. To investigate whether critical thinking significantly predicts EFL learners' indirect request strategy use, linear regression analysis was run. The results are summarised in Tables 2, 3, and 4. First, Table 2 indicates the simple correlation coefficient and the adjusted and unadjusted correlations of critical thinking with EFL learners' indirect request strategy use.

\section{Table 2}

Model Summary, Investigating the simple Correlation Coefficient, the Adjusted and Unadjusted $R$ of Critical Thinking with Indirect Request Strategy Use

\begin{tabular}{cccc}
\hline $\mathrm{R}$ & $\mathrm{R}$ square & Adjusted R square & Std. Error of the estimate \\
\hline .532 & .283 & .276 & .29042 \\
\hline
\end{tabular}

As the results in Table 2 show, the simple correlation coefficient $(\mathrm{R})$, between the predictor (i.e. critical thinking) and the dependent variable (i.e. indirect request strategy use) is $0.53\left(\mathrm{R}^{2}=0.28\right)$ and it indicates a high degree of correlation. In addition it shows that the adjusted $\mathrm{R}$ squared is 0.27 . It indicates that $27 \%$ of the variance in the indirect request strategy use of participants can be predicted from their critical thinking. In Table 3 the significance of the linear regression analysis was corroborated. 
On the relationship between critical thinking and indirect request strategy use of EFL learners

Table 3

ANOVA, Investigating the Prediction of Indirect Request Strategy Use of the EFL Learners' Critical Thinking

\begin{tabular}{llllll}
\hline & Sum of squares & df & Mean square & F & Sig. \\
\hline Regression & 3.267 & 1 & 3.267 & 38.729 & .000 \\
Residual & 8.266 & 98 & .084 & & \\
Total & 11.532 & 99 & & & \\
\hline
\end{tabular}

As shown in Table 3, the regression equation explained a significant portion of the variability in the EFL learners' indirect request strategy use from the variability in their critical thinking. Table 4 shows the amount of contribution of critical thinking to the dependent variable (i.e. EFL learners' indirect request strategy use).

Table 4

Linear Regression, Investigating the Predictive Power of Critical Thinking for the EFL Learners' Indirect Request Strategy Use

\begin{tabular}{|c|c|c|c|c|c|}
\hline & \multicolumn{2}{|c|}{ Unstandardized coefficients } & \multirow{2}{*}{$\frac{\text { Standardised coefficients }}{\text { Beta }}$} & \multirow[b]{2}{*}{$\mathrm{t}$} & \multirow[b]{2}{*}{ Sig. } \\
\hline & $\mathrm{B}$ & Std. Error & & & \\
\hline Critical thinking & 2.258 & .363 & .532 & 6.223 & .000 \\
\hline
\end{tabular}

As the results of linear regression analysis indicate, critical thinking was a significant and strong predictor of EFL learners' indirect request strategy use.

\section{Discussions}

Examinations of how EFL learners' critical thinking relates to their indirect request strategy use are rare. To address this issue the present study sought to investigate the possible relationship between critical thinking and EFL learners' indirect request strategy use. The results revealed significant relationship between the two variables. The results further revealed that critical thinking could strongly predict EFL learners' indirect request strategy use. It was revealed that the learners who received a high score in the CCTST had a high score in the EDCT (i.e. used more conventional indirect requests), those who received a low score in the CCTST, had a low score in the EDCT (i.e. used non-conventional indirect requests and/or direct requests). As a result critical thinking was assumed to significantly correlate with and predict EFL learners' indirect request strategy use.

Following Wang (2009), critical thinking ability could be assumed as the ability to think reflectively and reasonably. In line with Wang (2009), Ghaemi and Taherian (2011) claimed that learners who thought critically asked appropriate questions, collected relevant information and by logical reasoning came to reliable conclusions. Similarly, Sahamid (2014) proposes that critical thinkers give more reasons and justify their claims in supporting an argument. Furthermore, following Brown and Levinson (1987), higher levels of indirectness may result in higher levels of politeness. As a result, it might be assumed that EFL learners who frequently use polite and indirect request strategies would first analyse their thought about a request strategy and then select an indirect request strategy. Additionally, it might be proposed that making the indirect requests by EFL learners is motivated by the need to think critically and/or it might be assumed that EFL learners who think reflectively and reasonably may use more polite and indirect request strategies.

The learners with high levels of critical thinking are supposed to challenge almost everything they encounter and they express their disapproval and doubt by asking more questions (Davidson, 1998). Wang (2009) proposes that these learners have the inclination to freely express their own ideas; they demonstrate the interrelationships among the ideas and generate higher levels of thinking. It could be suggested that the learners who ask more questions and challenge almost everything they encounter use more polite and indirect request strategies when using English as a foreign and target language.

Facione (2011) proposes that the ideal critical thinkers are habitually inquisitive (i.e. they ask too many questions and try to find out too many details about their questions), well-informed (i.e. they are highly 
competent about one particular subject or many subjects), open-minded (i.e. they care about other people's ideas and opinions), prudent in making judgements (i.e. they form an opinion after thinking carefully about it). Therefore, following the claims of Facione (2011) and based on the findings of the present study it could be suggested that EFL learners with an ideal critical thinking are more willing to use indirect request strategies when they make their enquiries, they know a lot about choosing and using the indirect request strategies and simultaneously very meticulous about their addressee's opinions and ideas.

Soodmand Afshar and Rahimi (2014) indicated that critical thinking strongly predicted the learners' speaking ability. In line with the findings of the present study, the aforementioned finding of Soodmand Afshar and Rahimi (2014) might indicate that EFL learners with a high level of critical thinking (as they are more competent in speaking) by applying the indirect request strategies can speak with their interlocutors as much as is needed to make all their enquiries, think about all the responses painstakingly, interpret them and finally evaluate how helpful, useful and successful they were.

In order to request politely or formally for something EFL learners with a high level of critical thinking try to analyse, interpret, evaluate and draw conclusions inductively and deductively. EFL learners who think critically possess higher-level thinking skills. Accordingly, they are more able to think deeply, analyse the situation and between a direct and an indirect request choose the more polite and formal one (i.e. indirect request). Therefore, critical thinkers might be assumed to be more courteous and tactful speakers and do not bore their interlocutors by asking a lot of questions since they use indirect request strategies that might maintain the conversation or discussion for a long period of time.

As Blum-Kulka (1987) pointed out, conventional indirectness in requests is pragmatically clear and concerns about face saving constraints, therefore, it can be considered more polite. However, the illocutionary acts might be perceived as lacking politeness if they are highly indirect, which might not be regarded as pragmatically clear (Blum-Kulka, 1987). As a result, critical thinkers who have a high level of speaking ability can involve others in their discussions by caring about face saving constraints and using pragmatically clear language. Rue et al. (2007) point out that the higher the power status of the person one is speaking to/with the more indirect request strategies are used. EFL learners might need to use more indirect request strategies to communicate with their teachers who have a higher power status and make all their enquiries. Critical thinkers who are competent enough in using indirect request strategies (as was found in the present study) might be more able to establish and control such a communication. Hence, EFL learners who are highly competent in critical thinking might be assumed as more active and successful learners in the classroom (Soodmand Afshar \& Rahimi, 2014; Soodmand Afshar et al., 2014; Yang, 2012).

\section{Conclusions and Implications}

The findings of the study revealed that critical thinking and indirect request strategy use of EFL learners were significantly correlated. The study also found that critical thinking significantly predicted EFL learners' indirect request strategy use. The findings of the study could benefit EFL teachers, learners, material developers, and textbook designers. As in some EFL teaching and learning contexts teachers are the only authorities to conduct and run the class, and learners are more passive and reluctant in asking questions and solving their own problems, it behoves EFL teachers to teach and promote EFL learners' critical thinking, as a result the EFL learners can use their higher-order thinking skills to ask more questions and solve their own problems. EFL teachers can encourage the critical thinking in EFL learners who are already competent in thinking critically, as a result the indirect request strategy use of EFL learners might be increased dramatically. In addition, they can use some techniques in teaching methods and promote critical thinking in EFL learners who are not competent enough in thinking critically, whereupon the EFL learners might become more capable in using indirect request strategies which is considered polite rather than using direct request strategies which might be perceived less polite or impolite. EFL learners can also benefit from the findings of the study. EFL learners with a high level of critical thinking might prefer to use more indirect request strategies which are more polite and formal. Material 
developers and textbook designers could develop some techniques in the EFL learners' materials and textbooks to promote EFL learners' critical thinking and further enhance their abilities in using indirect request strategies. They can include higher-order thinking skills such as critical thinking skills in different exercises and tasks and other sections of the textbooks.

Acknowledgements: The researcher would like to thank the institutes in Sanandaj for their significant contribution in the data collection. The researcher is also deeply indebted to the participants of the study who generously spent their time taking the two tests.

\section{References}

Anani Sarab, M. R., \& Alikhani, S. (2015). Pragmatics instruction in EFL context: A focus on requests. International Journal of Research Studies in Language Learning, 5(1), 1-14. http://dx.doi.org/10.5861/ijrs1l.2015.1083

Austin, J. (1962). How to do things with words. In A. Jaworski, \& N. Coupland (Eds.), The discourse reader (pp. 63-75). New York: Routledge.

Balci, B. (2009). A comparative study on the performance of the requests and apologies by Turkish and American teenagers: A pragmatic competence point of view. Masteral thesis. Adana: University of Cukurova.

Birjandi, P., \& Alizadeh, I. (2012). Manifestation of critical thinking skills in the English textbooks employed by language institutes in Iran. International Journal of Research Studies in Language Learning, 2(1), 27-38. http://dx.doi.org/10.5861/ijrsll.2012.100

Blum-Kulka, S. (1987). Indirectness and politeness in requests: Same or different? Journal of Pragmatics, 11(2), 131-146. http://dx.doi.org/10.1016/0378-2166(87)90192-5

Blum-Kulka, S., \& Olshtain, E. (1984). Requests and apologies: A cross-cultural study of speech act realization patterns. Applied Linguistics, 5(3), 196-213. http://dx.doi.org/10.1093/applin/5.3.196

Brabeck, M. M. (1983). Critical thinking skills and reflective judgment development: Redefining the aims of higher education. Journal of Applied Developmental Psychology, 4(1), 23-34. http://dx.doi.org/10.1016/0193-3973(83)90056-4

Brown, P., \& Levinson, S. C. (1987). Politeness: Some universals in language usage. Cambridge: Cambridge University Press.

Davidson, B. W. (1998). A case for critical thinking in the English language classroom. TESOL Quarterly, 32 , 119-123. http://dx.doi.org/10.2307/3587906

Demirhan, E., Beşoluk, Ş., \& Önder, İ. (2011). The change in academic achievement and critical thinking disposition scores of pre-service science teachers over time. Western Anatolia Journal of Educational Sciences, 403-406.

Dewey, J. (1933). How we think (Revised ed.). D.C. Heath, Boston.

Dwyer, C. P., Hogan, M. J., \& Stewart, I. (2015). The effects of argument mapping-infused critical thinking instruction on reflective judgement performance. Thinking Skills and Creativity, 16, 11-26. http://dx.doi.org/10.1016/j.tsc.2014.12.002

Economidou-Kogetsidis, M. (2013). Strategies, modification and perspective in native speakers' requests: A comparison of WDCT and naturally occurring requests. Journal of Pragmatics, 53, 21-38. http://dx.doi.org/10.1016/j.pragma.2013.03.014

Erving, G. (1967). Interaction ritual: Essays on face to face behavior. Chicago: Aldine Publishing Company. Facione, P. A. (2011). Critical thinking: What it is and why it counts. Millbrae, CA: California Academic Press.

Facione, P. A., \& Facione, N. C (1993). The California critical thinking skills test: Form A and form B, test manual. Millbrea, CA: Callifornia Academic Press.

Facione, P.A., Facione N. C., Blohm, S., Howard, K., \& Giancarlo, C. (1998). The California critical thinking skills test manual. Millbrae, CA: California Academic Press.

Fahim, M., \& Mirzaii, M. (2013). Improving EFL argumentative writing: A dialogic critical thinking approach. 
Rahimi, M.

International Journal of Research Studies in Language Learning, 3(1), 3-20.

Ganapathy, M., \& Kaur, S. (2014). ESL students' perceptions of the use of higher order thinking skills in English language writing. Advances in Language and Literary Studies, 5(5), 80-87.

Ghaemi, H., \& Taherian, R. (2011). The role of critical thinking in EFL teachers' teaching success. MJAL, 3(1), $8-22$.

Jalilifar, A. (2009). Request strategies: Cross-sectional study of Iranian EFL learners and Australian native speakers. English Language Teaching, 2(1), 46-61. http://dx.doi.org/10.5539/elt.v2n1p46

Khatib, M., \& Shakouri, N. (2012). Literature stance in developing critical thinking: A pedagogical look. International Journal of Research Studies in Language Learning, 2(4), 101-108. http://dx.doi.org/10.5861/ijrsll.2012.154

King, P. M., \& Kitchener, K. S. (1994). Developing reflective judgment: Understanding and promoting intellectual growth and critical thinking in adolescents and adults. San Francisco: Jossey-Bass.

Koike, D. A. (1989). Pragmatic competence and adult L2 acquisition: Speech acts in interlanguage. The Modern Language Journal, 73, 279-289. http://dx.doi.org/10.1111/j.1540-4781.1989.tb06364.x

Liaw, M. (2007). Content-based reading and writing for critical thinking skills in an EFL context. English Teaching and Learning, 31(2), 45-87.

Lloyd, M., \& Bahr, N. (2010). Thinking critically about critical thinking in higher education. International Journal for the Scholarship of Teaching \& Learning, 4(2), 1-16.

Lun, V. M. C., Fischer, R., \& Ward, C. (2010). Exploring cultural differences in critical thinking: Is it about my thinking style or the language I speak? Learning and Individual Differences, 20(6), 604-616. http://dx.doi.org/10.1016/j.lindif.2010.07.001

Malaz, I., Rabiee, M., \& Ketabi, S. (2011). The pragmatic instruction effects on Persian EFL learners' noticing and learning outcomes in request forms. Journal of Technology of Education, 5(3), 187-193.

Manalo, E., Kusumi, T., Koyasu, M., Michita, Y., \& Tanaka, Y. (2013). To what extent do culture-related factors influence university students' critical thinking use? Thinking Skills and Creativity, 10, 121-132. http://dx.doi.org/10.1016/j.tsc.2013.08.003

McBride, R., \& Bonnette, R. (1995). Teacher and at-risk students' cognitions during open-ended activities: Structuring the learning environment for critical thinking. Teaching and Teacher Education, 11(4), 373-388. http://dx.doi.org/10.1016/0742-051X(94)00040-D

Mejia, A., \& Molina, A. (2007). Are we promoting critical autonomous thinking? A discussion on conversational genres and whether they can help us answer this question. Cambridge Journal of Education, 37(3), 409-426. http://dx.doi.org/10.1080/03057640701546722

Memarian, P. (2012). The use of request strategies in English by Iranian graduate students: A case study. Unpublished Masteral thesis, Eastern Mediterranean University, Gazimağusa, North Cyprus.

Mohammadi, M., \& Tamimi Sa'd, S. H. (2013). Native speakers' assessment of (im)politeness of non-native speakers' requests. International Journal of Research Studies in Language Learning, 3(4), 23-40. http://dx.doi.org/10.5861/ijrsll.2013.591

Myers, B. E., \& Dyer, J. E. (2006). The influence of student learning style on critical thinking skill. Journal of Agricultural Education, 74(1), 43-52.

Nasirahmadi, A. (2014). The relationship between Iranian language learners' critical thinking ability and their reading comprehension achievement. International Journal of Research Studies in Language Learning, 3(7), 15-27. http://dx.doi.org/10.5861/ijrsll.2014.689

Nikou, F. R., Bonyadi, A., \& Amirikar, N. (2015). Investigating the relationship between critical thinking skills and the quality of Iranian intermediate TEFL students' writing. Advances in Language and Literary Studies, 6(2), 57-64.

Niu, L., Behar-Horenstein, L. S., \& Garvan, C. W. (2013). Do instructional interventions influence college students' critical thinking skills? A meta-analysis. Educational Research Review, 9, 114-128. http://dx.doi.org/10.1016/j.edurev.2012.12.002

Paton, M. (2011). Asian students, critical thinking and English as an academic lingua franca. Analytic Teaching and Philosophical Praxis, 32(1), 27-39. 
On the relationship between critical thinking and indirect request strategy use of EFL learners

Rezaee, M., Farahian, M., \& Ahmadi, A. M. (2012). Critical thinking in higher education: Unfulfilled expectations. Broad Research in Artificial Intelligence and Neuroscience, 3(2), 64-73.

Rose, K. (1994). On the validity of the discourse completion task in non-western contexts. Applied Linguistics, 15(1), 1-14. http://dx.doi.org/10.1093/applin/15.1.1

Rue, Y. J., Zhang, G., \& Shin, K. (2007). Request strategies in Korean. In 5th Biennial Korean Studies Association of Australasia Conference (pp. 112-119). Perth, Australia.

Saadé, R. G., Morin, D., \& Thomas, J. D. (2012). Critical thinking in e-learning environments. Computers in Human Behavior, 28(5), 1608-1617. http://dx.doi.org/10.1016/j.chb.2012.03.025

Sahamid, H. (2014). Fostering critical thinking in the classroom. Advances in Language and Literary Studies, 5(6), 166-172.

Shahrokhi, M. (2012). Perception of dominance, distance and imposition in Persian males' request speech act strategies. Procedia-Social and Behavioral Sciences, 46, 678-685. http://dx.doi.org/10.1016/j.sbspro.2012.05.181

Sofwan, A., \& Rusmi. (2011). The realization of request strategies by non-native speakers of English. Ragam Jurnal Pengembangan Humaniora, 11(2), 69-81.

Soodmand Afshar, H., \& Rahimi, M. (2014). The relationship among emotional intelligence, critical thinking, and speaking ability of Iranian EFL learners. Teaching English Language and Literature Society of Iran, 8(1), 31-59. http://dx.doi.org/10.1016/j.sbspro.2014.05.291

Soodmand Afshar, H., \& Rahimi, M. (2015). Reflective thinking, emotional intelligence, and speaking ability of EFL learners: Is there a relation? Thinking Skills and Creativity. http://dx.doi.org/10.1016/j.tsc.2015.10.005

Soodmand Afshar, H., Rahimi, A., \& Rahimi, M. (2014). Instrumental motivation, critical thinking, autonomy and academic achievement of Iranian EFL learners. Issues in Educational Research, 24(3), 281-298.

Tajeddin, Z., \& Tayebipour, F. (2012). The effect of dynamic assessment on EFL learners' acquisition of request and apology. Journal of Teaching Language Skills, 4(2), 87-118.

Takahashi, S. (1992). Transferability of indirect request strategies. University of Hawaii Working Papers in ESL, $11,69-124$.

Tan, K. H., \& Farashaiya, A. (2012). Utilizing formulaic request strategies in an ESL classroom. Procedia-Social and Behavioral Sciences, 59, 42-46. http://dx.doi.org/10.1016/j.sbspro.2012.09.243

Umar, A. M. A. (2004). Request strategies as used by advanced Arab learners of English as a foreign language. Umm Al-Qura University Journal of Education and Social Sciences and Humanities, 16(1), 42-87.

van Gelder, T. J. (2001). How to improve critical thinking using educational technology. In G. Kennedy, M. Keppell, C. McNaught, \& T. Petrovic (Eds.), Meeting at the crossroads. Proceedings of the 18th annual conference of the Australian society for computers in learning in tertiary education (pp. 539-548). Melbourne: Biomedical Multimedia Unit, the University of Melbourne.

Wang, Y. H. (2009). Incorporating critical thinking skills into an English conversation program. European Journal of Social Sciences, 11(1), 51-60.

Yang, Y. T. C. (2012). Cultivating critical thinkers: Exploring transfer of learning from pre-service teacher training to classroom practice. Teaching and Teacher Education, 28(8), 1116-1130. http://dx.doi.org/10.1016/j.tate.2012.06.007 
Rahimi, M. 